\title{
CONSTITUCIONALISM AND THE DEVELOPMENT OF BRAZILIAN CONSTITUCIONAL LAW
}

\author{
Jadson Correia de Oliveira* \\ José Elio Ventura da Silva**
}

\begin{tabular}{l|l}
\hline RECEBIDO EM: & 12.3 .2020 \\
\hline APROVADO EM: & 10.4 .2020 \\
\hline
\end{tabular}

* Pós-doutor em Democracia e Direitos Humanos pelo Ius Gentium Conimbrigae/Centro de Direitos Humanos (IGC/CDH) da Universidade de Coimbra, doutor em Direito pela Pontifícia Universidade Católica de São Paulo (PUC-SP), mestre em Direito pela Universidade Católica de Pernambuco (Unicap) e especialista em Direito Público pela Escola Superior da Magistratura de Pernambuco (Esmape). Professor do curso de Direito do Centro Universitário do Rio São Francisco(UniRios) e da Universidade Católica do Salvador(UCSal). Advogado. E-mail: jadson_correia@hotmail.com

** Doutorando em Direito da Universidade Católica de Pernambuco (Unicap) e mestre em Direito pela mesma instituição. Bolsista da Fundação de Amparo à Ciência e Tecnologia do Estado de Pernambuco (Facepe). Professor do curso de Direito do Centro Universitário do Rio São Francisco (UniRios). Advogado. E-mail: elio.adv@hotmail.com 
- ABSTRACT: As the following work revisits constitutionalism aims not only to address the topic of limitation of the state branches, but also to analyze the importance of constitutional law and jurisdiction for the concretion of the Brazilian Democratic State. Hence, the focus on neoconstitutionalism is intended to praise the highlights of this movement and the paradigmatic shifts that it fostered after World War II, especially with regard to the so-called materialization of the constitution. The draft dedicated to the history of constitutionalism and constitutional law in Brazil aims to demonstrate the scenario of weaknesses and misconceptions present in the Brazilian historical-constitutional process, without disregarding the importance of the analysis. This study concludes that although constitutional law in Brazil has been disassociated from the essence of constitutionalism for many years, the 1988 Constitution was a milestone to the resurgence of South American constitutionalism and the concern over the concretion of rights through constitutional jurisdiction.

$\square$ KEYWORDS: Brazilian constitutionalism; neoconstitutionalism; constitutional jurisdiction.

\section{O CONSTITUCIONALISMO E A CONSTRUÇÃO DO DIREITO CONSTITUCIONAL NO BRASIL}

REsumo: $\bigcirc$ trabalho, ao revisitar o constitucionalismo, almeja não apenas abordar o tema da limitação dos poderes estatais, mas também analisar a importância do direito e da jurisdição constitucional para a concretização do Estado Democrático brasileiro. Dessa forma, o enfoque dado ao neoconstitucionalismo objetiva enaltecer os pontos altos do movimento e as mudanças paradigmáticas por ele promovidas após a Segunda Guerra Mundial, especialmente no que diz respeito à chamada materialização da constituição. $\bigcirc$ esboço dedicado à história do constitucionalismo e do direito constitucional no Brasil busca apresentar o cenário de fragilidades e equívocos presentes no processo histórico-constitucional brasileiro, sem, contudo, desconsiderar a importância da análise. $\bigcirc$ estudo conclui que, apesar de o direito constitucional no Brasil, por longos anos, encontrar-se desassociado da essência do constitucionalismo, a Constituição de 1988 marcou o ressurgimento do constitucionalismo 
sul-americano e a preocupação com a concretização dos direitos por meio da jurisdição constitucional

- PALAVRas-chave: constitucionalismo brasileiro; neoconstitucionalismo; jurisdição constitucional.

\section{Introduction}

The idea of law emerges as a legitimate way for the state to exert social control over people, dictating behavior rules to them. All of that being done with a view to ensuring that human beings can live in a community. The central premise of the state arose from these roots, and moreover, this was the very reason for the creation of the defense of public interest. In order to achieve its desideratum, the state has instrumental powers that must be exerted with the intention of demonstrating all the strength of the state, so that the proper order is preserved.

One can derive, from the concepts espoused, the rise of the movement entitled constitutionalism, which is linked to the notion and to the importance given to a constitution, once the state is a supreme being, the citizens must have the means to guarantee their civil liberties, in order to regulate the way that the state powers are exerted: "The state, thus, manifests itself as a deliberate and conscious creation of the will of the individuals who form it, in accordance with the doctrines of social contractualism" (BONAVIDES, 2011, p. 41).

The need to establish limitations on the powers of governing authorities, as well as the respect to the rights of the governed people, gave rise to the political-philosophical movement of constitutionalism, inspired by libertarian ideas that sought, from its very first steps, a political organization model.

In this context, constitutional law, and especially constitutionalism, occupied and shall occupy a prominent role in the development process of the most distinct civilized societies, evidently respecting their inherent peculiarities in terms of time and space.

It is indeed true that the path taken by the institutes which have been chosen to be analyzed here was not always linear. Most of the times, notably in the history of constitutional law and constitutionalism in Brazil, there is a real regression of the process, with substantial drawbacks. 
Therefore, the work has as a nodal point of approach to raise, first of all, the interest in understanding the constitutionalism around the world, and then attempt to understand the institutes from the Brazilian reality, focusing on the constitutions that took place from the Independence of the country until the Constitution(also known as “The Citizen Charter") of 1988, that is currently in force.

In order to achieve its goal, the analysis focuses on four points, namely: 1 . the role played by constitutionalism from an international perspective; 2 . the impacts caused by neoconstitutionalism; 3. the historical trajectory of constitutionalism and constitutional law in Brazil; and 4. the construction of the Brazilian constitutionality control system from the expansion of constitutional jurisdiction.

The first line of investigation aims to present the inherent notions to constitutionalism, their importance from the historical point of view (the connection with the agenda of the guarantee of rights and the establishment of limitations on the power of governing authorities) since the 5 th century B.C. to the present day, the most different types of constitutionalism (ancient, liberal, social and contemporary), the first written constitutions and their repercussions, as well as the inherent peculiarities to this movement in the face of this historical process.

The second point of analysis will approach neoconstitutionalism from a paradigmatic perspective in the process of understanding constitutionalism, taking as a milestone the end of World War II and its repercussions. It will be especially considered at this point the transferring of the leading role from the Legislative State of Law to the so-called Constitutional State of Law, mainly considering the importance assumed by the dignity of the human person.

The third component will present an analysis regarding the historical process of constitutionalism and constitutional law in Brazil, starting from the Empire Constitution up to the 1988 Constitution, which is currently in force. On the occasion, the main influences received by the movement in Brazilian lands, the relevant facts that gave rise to the models adopted by the constitutional charters and the consequences arising from the choices made will be presented.

The fourth focal point of this study, in turn, is regarding the importance of the control of constitutionality, based on the one exerted in Brazil. Therefore, in order to maintain the integrity of the constitutional norms and, consequently, of the legal system, control systems have been developed for the acts that somehow violate the constitutional text. 
Finally, it is of salutary importance to mention the fact that, in Brazil, the current Constitution of the Republic, especially for its volume of content, has got countless colliding premises; it is a true dialectical text. This fact in itself does not exclude the importance of the content conveyed in the constitutional norm, but it enables the existence of a legal system that is diversified and attentive to social changes, creating the necessary space for the expansion of constitutional jurisdiction, beyond the mere idea of a negative and legislator Judiciary Branch. In such a context, the Judiciary Branch "represents the privileged space to enforce the fundamental rights assured in the constitution (democracy of rights), as well as to recognize them and give them effectiveness" (ZANETI JR., 2013, p. 425).

\section{The role of constitutionalism in Continental Europe and in the United States}

Constitutionalism is presented as an instrument aimed at the guarantee of rights and the establishment of limits against abuses and arbitrariness committed by absolutism. It was, therefore, a political and philosophical movement that stood long before the idea of written constitution along the lines of the American constitution of 1787 and the French constitution of 1791.

Indeed, one cannot think of constitutionalism without considering the perspective of the freedom of people. In this sense, it is very clear in this movement the fact that there is no way to conceive a guarantee of civil liberties without restricting or imposing limits on the power of the governing authorities.

It is possible to say, from a more didactic perspective, that constitutionalism is subdivided into quite different moments. Part of it is in classical ancient times, then, it evolves until it reaches the medieval (English) model, then it migrates to the liberal (American and French) model, moves towards the social model until it reaches the contemporary model.

Regarding the ancient constitutionalism, it is noteworthy, besides the Athenian model, that would impose a severe limitation on the political power and would give to the people the possibility to participate directly of the government (5th to 3rd centuries B.C.), the Roman model (5th to 2 nd centuries B.C.) that inaugurated a type of reciprocal control among powers as a way to impose limitations, which in the future would be called the checks and balances system (CUNHA JUNIOR, 2018, p. 30-31). 
Following this reasoning, constitutionalism has evolved, having as a milestone the subscription of the Magna Carta ("The Great Charter of the Liberties") of 1215, by King John I "Lackland", King of England. Although he was not actually concerned with civil liberties and the guarantee of rights of his subjects, he ended up contemplating interesting guaranteeing instruments to a quite specific group of people, it is really true, notably the barons; but in practice he would make room for achievements such as the due process of law, freedom of movement, and property.

After the advances promoted by the English constitutionalism, from the seventeenth century onwards the need to go through other pathways was intensified, making room for what the eighteenth century decided to name as liberal constitutionalism. This movement was mainly marked by the creation of the first written constitution, the American constitution of 1787. It had as its founding elements, besides the civil liberties and rights, the imposition of limits on the governing authorities, by means of a strict document which was hierarchically superior to any others, as it is withdrawn from the excerpt below:

Therefore, in modern constitutionalism, the constitution is no longer conceived as a mere political aspiration for freedom, instead, it is now understood as a written and fundamental text, designed to fulfill two functions: organization of the state and limitation of the state power, through a declaration of fundamental rights and guarantees (CUNHA JUNIOR, 2018, p. 34).

Liberal constitutionalism succeeded in obtaining relevant achievements, however, as in any other analysis, it is imperative that its trajectory be assessed from a point of view that is capable of removing a biased look from the process of understanding. This is mentioned because, despite the idea of universalism, with regard to freedom, especially, this historical moment was also marked by the non-recognition of the rights of a large portion of the population; just consider the exclusion of slaves, women, men of color and indigenous people. In this regard, see the interesting quote below:

One of the fundamental premises for the imputation of rights was to be endowed with talent and reason. Therefore, to promote the exclusion of the "others", they theorized about the absence of the ability for reasoning of the native or indigenous people and blacks, and, as a result, they were considered "in natura" beings, without self-governing abilities. From this, they were excluded from the social pact, which would order the new constitutional society (MONTAÑEZ, 2014, p. 284). 
In practice, according to the constitutionalism from the United States, there was a speech of freedom for the white man and an extreme omission towards other individuals, founded on a political necessity to maintain slavery. Hence, the constitution from the United States avoided talking about slaves and blacks, using, instead, the expression "others persons" (MONTAÑEZ, 2014, p. 288) as a way of excluding these people.

In this scenario, the revolution of the Haitian people of 1804 proved to be quite impactful on both American and French constitutionalism, since the deliberate exclusion of certain groups of people imposed a rethinking regarding the ideals of liberty, equality and universality, especially because the proposal of universalism was quite close to something deeply rhetorical.

As a result of the exhaustion of the liberal model, linked to the idea of the guarantee of rights, based almost exclusively on freedom and on the separation of powers, the social discussion (nineteenth century) emerged; it was a topic that, until then, had actually been viewed with quite indifference by the Liberal State. The need to rethink the pure and simple liberalism made the state become purposeful and, therefore, a service provider. As a result, the widening of fundamental rights became visible, notably after Weimar constitution and the post-war European constitutions (SANTOS, 2010, p. 217).

As this historical moment was overcome, the pathways were directed to the so-called contemporary constitutionalism or neoconstitutionalism, which was inaugurated from the twentieth century; it has a strong value load in the Constitution, dedicated to seeking solutions to the most diverse and complex conflicts. This is all because, as announced by Hesse (1991, p. 20), "as it was stressed, it is an essential requirement of the normative force of the constitution, that it takes into account not only the dominant social, political, and economic elements, but also that it mainly embodies the spiritual state of its time".

\section{The achievements accomplished by neoconstitucionalism}

Neoconstitutionalism established a new way of thinking the constitutional law, replacing a purely legislative standard that, disconnected from any perspective of reasonableness, saw in the legislation the main foundation for the law. One can just consider 
the horrors carried out by the German model during the Word War II, whose conduct was "justified" by the attachment to extreme legalism.

In this sense, some scholars view the rise of neoconstitutionalism after World War II, however, some others believe that this historical moment only revealed the beginning of the contributions fostered by the movement, having the turn of the century as its true milestone (MOREIRA, 2008, p. 28).

This paradigmatic shift resulted indelibly from the dissatisfaction with this imposing pattern of offenses and abuses of rights, bringing about the need to rethink the legal order from the dignity of the human person and fundamental rights, which imposed the transferring of the leadership role of the Legislative State to the so-called State ruled by constitutional law, it even caused a modification in the constitutional texts of contemporaneity. In Brazil, neoconstitutionalism is more evident from the 1988 Constitution onwards (CUNHA JUNIOR, 2018, p. 35-36).

The principles did not gain much relevance until the appearance of neoconstitutionalism; however, with this new constitutional movement, the principles began to have normative force. Therefore, several are the contributions promoted by neoconstitutionalism.

Neoconstitutionalism or new constitutional law, within the meaning defined here, identifies a broad set of transformations that took place in the state and in constitutional law, of which may be pointed out; (i) as a historical milestone, the development of the State ruled by constitutional law, whose consolidation occurred over the last decades of the twentieth century; (ii) as a philosophical milestone, post-positivism, with the centrality of fundamental rights and the rapprochement between law and ethics; and (iii) as a theoretical milestone, the set of modifications that include the normative force of the Constitution, the expansion of constitutional jurisdiction and the development of a new dogmatic theory of constitutional interpretation. This set of phenomena resulted in an extensive and profound process of constitutionalization of the law (BARROSO, 2005, p. 15).

The Constitution, with this new look and appearance of constitutionalism, moved away from the condition of merely a political document and gained the necessary strength to place itself in a condition of superiority before all the powers constituted by it. An important truth is that the neoconstitutionalist model of Constitution removed the leading role from the legislature. 
The constitutional charters, therefore, as they absorbed moral and political values, a phenomenon that is also, sometimes, called materialization of the Constitution, linked to the idea that the power emanates from the people and is exercised by their representatives, emphasized what has been agreed to be named neoconstitutionalism (MENDES, 2012, p. 53).

In this regard, it should be noted that the relationship between constitutionalism and fundamental rights is also inevitable and, as constitutionalism expands, the catalog of fundamental rights is also widened, notably when one looks at the trajectory taken to reach neoconstitutionalism, because "it is the very material notion of constitution that is altered when new material rights are recognized" (SANTOS, 2011, p. 63). In this respect, it is worth presenting Paolo Comanducci's (2002, p. 97) explanation:

\footnotetext{
Neoconstitutionalism, as a theory of law, aims to describe the advances of constitutionalization, that is, of this process that included a modification of the great contemporary legal systems in relation to those existing before the full implementation of the process itself. The model of the legal system that emerges from the reconstruction of neoconstitutionalism, in addition to an "invasive" constitution, is characterized by the positivization of a catalog of fundamental rights, the omnipresence in the constitution of principles and rules, and by some peculiarities of the interpretation and the application of the constitutional norms regarding the interpretation and law enforcement.
}

Despite the importance of this constitutional movement, it obviously does not claim to be eternalized or even universalized, even because the need for change is part of the evolutionary process of society, similar to that has occurred with the liberal and social models, that, over time, gave way to each other until they reached this neoconstitutionalist standard. It does not claim to universalize itself, noticeable because it excludes the undemocratic countries, as well as those nations which have a constitutional model that is deprived of guarantees and with largely restricted fundamental rights. From this reasoning, Eduardo Ribeiro Moreira (2008, p. 31) also adds that "the next step is continental constitutionalism, a (almost) European reality that is already beginning to be faced by neoconstitutionalism".

Finally, it is interesting to highlight that the paradigm carried by neoconstitutionalism was strongly considered within Italian and Spanish law and, from the Latin American perspective, countries such as Argentina, Brazil, Colombia and Me- 
xico gave it a remarkable degree of importance as well (CARBONELL; JARAMILLO, 2010, p. 153).

\section{The historical trajectory of constitutionalism and constitutional law in Brazil}

Brazilian constitutionalism cannot be conceived under a genuinely Brazilian bias, notably because of its historic dependence on the Kingdom of Portugal. In addition to that, this movement, essentially focused on the limitation of powers and the guarantee of rights, initially received a major influence of the French model.

Article 16 of the Declaration of the Rights of Man and of the Citizen (August, 1789) in turn, is quite emblematic in respect of the need to guarantee rights and separate powers as a condition for considering whether a constitution exists or not: "Toute societé dans laquelle la garantie des droits n'est pas assurée ni la séparation des pouvoirs determiné, n'a point de constitution" ("A society in which the observance of the law is not assured, nor the separation of powers defined, has no constitution at all”) (BONAVIDES, 2000, p. 158). Regarding the historical background of the initiation of constitutionalism in Brazil, it is worth pointing out that while its embryo appeared around 1808 in Portugal, with the so-called "Supplications" to Bonaparte -, a sort of text similar to a proposal for a constitution, a request for a "grant" or a "donated letter", here, it can be said that the Brazilian starting point was brought about by the Pernambucan Revolution in 1817, with a strong republican impetus. This model was in fact a constituent act, as emphasized by Professor Bonavides (2000, p. 160).

The document of 1817 enshrined advanced formulas of power organization, settled in the doctrine of the sovereign people; in the convocation of a constituent convention; in tolerance of all Christian sects, once Roman Catholicism would be established as the state religion; in the prohibition of persecution acts for reasons of conscience; in the guarantee and stability of the judicature; in the proclamation of freedom of press; in the calling for responsibility of the governing authorities whose acts would undermine the sovereignty of the people and the rights of man, therefore, it is equivalent to the institute that, in a presidential form of government, was named "impeachment"; in the creation of a Supreme Court and finally in the recognition that the Constituent Convention is the seat of the legitimate power delegated by the people, as inferred by the article 28 . 
It was certainly a very representative text. Thus, it was clear that the relationship with Portugal was already rather tense, as Brazil was fighting for its independence, despite the efforts of some segments aiming at a constitutional unity.

Brazil granted its constitution in 1824, with the disruption between the countries, which beyond the creation of rights and establishment of duties, it imposed on the moderating power branch, in a visible defiance to the rule of separation of power branches and the limitation of these branches, according to the principle of checks and balances, spread by Montesquieu. It is nearly impossible not to conclude that this constitutional model was quite distant from the essence of constitutionalism.

A new constitution was inaugurated in 1891, with the end of the empire in 1889 and the beginning of the republican period. It was guided by a model that was no longer directly influenced by the French matrix; it had, instead, a visible approximation and inspiration to the American model of constitutionalism, characterized by federalism, the presidential governing system and the republican form of government.

Many people believed that the paradigm shift promoted by the drastic modification of the constitutional model would be the redemption of the country, yet, history has shown that the difficulties were gigantic, considering the country was not sufficiently prepared to face a republican format. The model of federation applied was extremely disassociated from the feature that had given its inspiration (the North American model) and the presidential system, in turn, was based on the "misrepresentation of electoral records" (BONAVIDES, 2000, p. 171), which undoubtedly compromised the idea of representativeness.

This period of frustration and turbulence was undoubtedly marked in the country's constitutional history, especially in the 1930s. However, times of crisis also give rise to challenges, raising the sense of the need for change. Consequently, the Constitutionalist Revolution of 1932 broke out in São Paulo, leading to the culmination of the Constitution of 1934, which was singularly representative of the Second Republic, although it lasted only three years.

The Constitution of 1934, still in this scenario of instability, made room to the authoritarian model of Getúlio Vargas, who granted a new constitutional charter in 1937. The Constitution of 1937 was responsible for establishing a noticeable drawback, as for instance the event of the closure of Brazilian Congress, the eagerness for the institutional strengthening of the Executive branch, the extinction of political parties and the "concentration of the executive and legislative power branches in the 
hands of the President of the Republic, who legislated through the use of decree-laws” (CUNHA JUNIOR, 2018, p. 454).

In practice, the country was in a situation of notable contempt for the constitutionalism genuinely focused on the limitation of powers, in spite of already having gone through four constitutions. There was, then, a sequence of errors and regressions, evidently keeping some advances obtained in the social area; that actually ended up serving to support the model, through the conquest of popular support.

Shortly after World War II and the end of the state of exception (by 1945), Brazil, in 1946, faced a different constitutional scenario. A period that praised a democratic model had begun, followed by the inauguration of its fifth constitutional charter. At that time, it was regarded as a relevant achievement, although there were the crises caused by the return of Getúlio Vargas to power between 1951 and 1954, the resignation of Jânio Quadros and the fall of João Goulart in 1964, on the occasion of the military coup.

In this constitutional path, the military coup irremovably and negatively marked Brazilian constitutional history, facing the collapse of the Constitutional Charter of 1946. This dismantling of the Constitution of 1946 by the 1964 coup culminated in a constitutional charter without any legitimacy, the 1967 Constitution, granted by the military regime.

Not satisfied with this arbitrary model of constitution, in 1969 the military regime approved an amendment to the 1967 Constitution, which in practice represented a new constitution with even greater powers to the executive branch and brought a blatant weakening of the Legislative Branch (CUNHA JUNIOR, 2018, p. 457). This pattern of restriction of rights, abuses, arbitrariness and excesses only faded out by the arrival of the 1988 Constitution, when for the first time in Brazilian constitutional history, it was understood the meaning of constitutionalism.

In the Brazilian case, the rebirth of constitutional law occurred in the context of reconstitutionalization of the country, during the previous discussions, convening, drafting and promulgation of the 1988 Constitution. Despite the vicissitudes of more or less seriousness in its text, and the compulsive form it has been amended over the years, the Constitution was able to successfully promote the crossing of the Brazilian state from an authoritarian, intolerant and at times violent regime to a democratic state ruled by law (BARROSO, 2005, p. 4). 
Bonavides (2000, p. 172) adds that: "As a constitution of the fundamental rights and legal protection of society, thus, combining the defense of the social body and protection of the subjective rights, it was a significant advance in the legal perspective of the regime".

\section{The implementation of constitutional review in Brazil and the expansion of constitutional jurisdiction}

In Brazil, the first Constitution was silent regarding the possibility of judicial review on the constitutionality of the laws. However, this mechanism was predicted to exist in Decree n. 848 from October 11th, 1890.

During the Empire period (Brazilian Constitution of 1824), there was no constitutional review and the power branches were divided into four: Legislative, Executive, Judiciary and Moderating branches, with the latter being in charge of the control of the others, under the power of the Emperor himself. The Imperial Constitution was semi-flexible, adopting an official religion as well. The regime, therefore, did not emphasize democracy in its institutions.

The Republican Constitution of 1891, in turn, represents a true shift in Brazilian institutional reality. It laicizes the state, makes it a federation and extinguishes the moderating branch. The real revolution in terms of constitutional process was the implementation of the system of checks and balances for the control of power. [...]. The Judiciary Branch, that formerly was a subordinate branch, began to act as a mediator of the branches, with the extinction of the Moderating Branch and the adoption of the judicial review technique (COUTO, 2012, p. 27).

The 1934 Constitution introduced a special quorum requirement to declare unconstitutionality, which is now being considered as a plenary reservation clause; the creation of the interventionist direct action and the Senate's grant to suspend the enforcement of a law declared unconstitutional by the Judiciary Branch (PIMENTA, 2010, p. 37).

The 1937 Charter kept the plenary reservation clause, but it was marked by a drawback when it developed a mechanism capable of annihilating the constitutionality review, by prescribing in the sole paragraph of article 96 , that: 
[...] if a law is declared unconstitutional, and in the judgment of the President of the Republic, it is necessary for the welfare of the people, the promotion or defense of a high national interest, the President of the Republic may refer it again to the assessment of the parliament; if confirmed by two thirds of votes in each of the Representatives' Houses, the decision of the Court of Appeals will not have any effect (PIMENTA, 2010, p. 37).

The 1946 Constitution promoted the recovery of the systematics outlined in the 1934 Charter and enhanced the Senate's role by determining that the suspension of law enforcement would only occur after the Supreme Court's final decision on unconstitutionality (PIMENTA, 2010, p. 37-38).

Still under the aegis of that Magna Carta, the constitutional amendment 16/1965 was enacted, giving rise to the abstract constitutionality review (PIMENTA, 2010, p. 38).

New changes in the Brazilian system of constitutionality review only came after the enactment of the 1988 Constitution. Among them, the following deserve a special mention: expansion of the active legitimacy for the proposition of direct action (art. 103); institution of direct action by omission (art. 103, $\$ 2^{\circ}$ ) and institution of the injunction warrant (art. $\left.5^{\circ}, \mathrm{LXXI}\right)$; creation of the action against the violation of a constitutional fundamental principle (art. 102, $\$ 1^{\circ}$ ); demand for the Federal Prosecutor's statement in all unconstitutionality actions, as well as the summons of the General Counsel for the Federal Government (art. 103, $\$ \$ 1^{\circ}$ e $3^{\circ}$ ); and modification of the extraordinary appeal, which now deals exclusively with the constitutional issues (art. 102, III) (PIMENTA, 2010, p. 37-38).

The very idea of a Constitutional Court acting as guardian of the Constitution must be seen in a more modern way, considering that it cannot be an apolitical judging entity, with the simple task of analyzing the constitutionality of ordinary laws, in a bias of bureaucratic application and detached from the law. This same court ought to be ruled by the will of the founders of the Constitution (MENDES, 2012, p. 56).

Therefore, while in the first system there is the possibility for any citizen to initiate the review of constitutionality, in the second one, only a specific list of legitimized people has such power.

When faced with a concentrated model, the specific instruments for provoking the Constitutional Court arise, so that it can analyze the constitutional matter. In this context, in Brazil, there is the direct action for the declaration of unconstitutionality ADIn, intended to control normative acts or federal or state laws that counteract the 
Constitution, the direct action for the declaration of constitutionality - ADC, destined to a federal law or normative act and the action against the violation of a constitutional fundamental principle - ADPF, which encompasses federal, state and municipal acts (TEIXEIRA, 2008, p. 260).

Nevertheless, such characteristics are no longer seen as differentiating factors, considering that in the diffuse model, on behalf of the uniformity of jurisdictional decisions, the doctrine of objectification of extraordinary appeal gains acceptance, in order to provide erga omnes effectiveness to the decision made in diffuse control of constitutionality.

In Brazil, the doctrine usually adopts the term "mulato" when referring to the way constitutionality review is carried out, since two different traditions, the American and the European, are in force (COUTO, 2012, p. 26).

However, it is necessary to mention that these distinctions about the subject have been seen as long outdated, as Zagrebelsky (2008, p. 64-65) states:

In spite of the differences between such constitutionality review systems of the laws, important approximations have occurred. The United States Supreme Court is a special judging entity of major issues of constitutionality, similar to the European constitutional courts, and on the other hand, the introduction of review of laws through preliminary ruling has placed European constitutional courts in the framework of ordinary justice, with similar results in many ways to the American system.

In addition to these discussions, another topic that constantly gives rise to academic concerns is whether the Judiciary Branch's control over constitutionality through which unelected judges controlling the acts of the elected legislator would be in tune with democracy.

In response to this inquiry, it is necessary to analyze the court responsible for controlling constitutionality not as a censoring body or just a negative legislator, but as singular deliberative courthouses, that is, the proper ground, so that the arguments prevail over vote counting, "decision-making venues that are essentially characterized by the effort to persuade and the openness to be persuaded through impartial reasons", instruments that convey the public reason (MENDES, 2012, p. 54).

When questioned about this issue, Häberle $(2009$, p. 4) states that in a Constitutional State, democracy is characterized by the division of powers, that is, no entity 
or body has sovereign power, which is the reason why it would be right to address a concept of constitutional sovereignty rather than a concept of social or state sovereignty.

The courts that will carry out the constitutionality review need to be open to the different minds that integrate society, so that they can form a justified discourse about the best foundation to be adopted in the judicial decision.

As a matter of fact, it can be concluded that Brazil has never adopted, in a pure way, the diffuse or concentrated model of constitutionality review, since in the U.S. concrete model there is the binding effectiveness of the Supreme Court decision due to the stare decisis rule; on the other hand, in the European-Kelsenian model, there is a need for the presence of a Constitutional Court as an entity outside the Judiciary Branch, something that has never existed since its implementation in Brazil.

For these reasons it was agreed to adopt the term "hybrid" to refer to the constitutionality review model implemented by Brazil.

Beyond that, it is worth mentioning that, as asserted on several occasions throughout the text of this investigation, the constitutionality review promoted by the Brazilian constitutional jurisdiction suffered several changes, mainly after the reforms promoted by the Constitutional Amendment 45/2004, making the old duality that is present between the two models no longer exists in a very clear way.

\section{Closing remarks}

Since it is an analysis that aimed to discuss and deepen issues related to constitutionalism, a movement historically present in the main civilized nations, especially regarding the movement in Brazil, it is possible to consider that the impressions provided by the study are positive, taking into account a possible contribution to the improvement of this topic.

The study allowed to demonstrate that constitutionalism in the world has become a political and philosophical movement of great significance, especially because when it establishes its bases in guaranteeing the right to the subjects and establishing limits to the absolute powers of the governing authorities, it undoubtedly succeeded in achieving great progress for humanity.

Neoconstitutionalism, in turn, represented a shift in the constitutional thinking, notably by boosting the reach of the State Ruled by the Law as a substitute for the lea- 
ding role of the Legislative State of Law, which admitted the greatest harm and arbitrariness under the adherence to legalism.

Consequently, it is noticeable that neoconstitutionalism aims to be a theory that opposes the two theses of conceptual positivism, the one of social sources of law and the non-necessary connection between law and morality.

Within neoconstitutionalism, the interpreter and the judge perform an activity formerly intended exclusively for the legislator, breaking with the idea outlined by classical positivism about the analysis of legal science concerning only with the legislator and emphasizing the judicial order as one of the means capable of promoting the development of constitutional jurisdiction and the evolution of the Constitution itself.

In this scenario, the advance of constitutional jurisdiction promoted by neoconstitutionalism, besides a new source for law, it represents a paradigmatic transformation of the jurisdictional function, where the Judiciary mitigates its role as a negative legislator and strengthens the premise of the realization of fundamental rights, for instance, through the constitutionality review.

With this paradigm shift, the constitution was no longer seen as a mere political document, but as a superior normative force before all the powers constituted by it, the fundamental rights were praised and the principles now are playing a prominent role. Undoubtedly, neoconstitutionalism remains quite representative.

The history of constitutionalism and constitutional law in Brazil has been marked by mistakes, misunderstandings and drawbacks since the Empire's Constitution of 1824. It cannot be forgotten that some achievements were noteworthy, especially in the social field. On the other hand, the constitutionalism thought of as an agent that limits power and guarantees rights was disassociated from its guiding principles for a long period.

As a matter of fact, the expansion phenomenon of the constitutional jurisdiction, which enabled the idealization of a constitutional justice based not only on a model of a negative legislator judge, found support in the neoconstitutionalism and in the concept of a Judiciary Branch that applies the fundamental rights envisaged by the constitution.

In Brazil, the constitutionality review evolved from a political-controlled model to a plural model, open to many minds, concerned with its legitimacy and cognitively influenced by public hearings and the participation of amicus curiae, in accordance with the idea that a constitution should not be seen as a document destined for jurists, but, rather, that all citizens are potential constitutional interpreters. 


\section{REFERENCES}

BARROSO, L. R. Neoconstitucionalismo e constitucionalização do direito: o triunfo tardio do direito constitucional no Brasil. Revista de Direito Administrativo, v. 240, p. 1-42, 2005.

BONAVIDES, P. A evolução constitucional do Brasil. Estudos Avançados, v. 14, n. 40, p. 155-176, 2000. BONAVIDES, P. Do Estado liberal ao Estado social. 10. ed. São Paulo: Malheiros Editores, 2011.

CARBONELL, M.; JARAMILLO, L. G. El canon neoconstitucional. Madrid: Trotta, 2010.

COMANDUCCI, P. Formas de (neo)constitucionalismo: un análisis metateórico. Isonomía, n. 16, p. 89-112, 2002.

COUTO, J. G. K. Controle difuso de constitucionalidade: efeito vinculante da sentença proferida pelo Supremo Tribunal Federal. In: MITIDIEIRO, D. (org.). O processo civil no Estado Constitucional. Salvador: JusPodivm, 2012.

CUNHA JUNIOR, D. da. Curso de direito constitucional. 12. ed. Salvador: JusPodivm, 2018.

HÄBERLE, P. Conversas acadêmicas com Peter Häberle. Org. Diego Valadés. Tradução Carlos dos Santos Almeida. São Paulo: Saraiva, 2009.

HESSE, K. A força normativa da Constituição. Porto Alegre: Sergio Antonio Fabris Editor, 1991.

MENDES, C. H. O projeto de uma corte deliberativa. In: SOUZA, R. P de et al. Jurisdição constitucional no Brasil. São Paulo: Malheiros Editores, 2012.

MONTAÑEZ, N. G. La revolución haitiana en los inicios del constitucionalismo: la cuestión de la raza y el sujeto jurídico y político. História Constitucional, n. 15, p. 279-310, 2014.

MOREIRA, E. R. Neoconstitucionalismo: a invasão da Constituição. São Paulo: Método, 2008.

PIMENTA, P. R. L. O controle difuso de constitucionalidade das leis no ordenamento brasileiro: aspectos constitucionais e processuais. São Paulo: Malheiros Editores, 2010.

SANTOS, G. F. (coord.). Constituição e constitucionalismo. Curitiba: Juruá, 2010.

SANTOS, G. F. Neoconstitucionalismo, Poder Judiciário e direitos fundamentais. Curitiba: Juruá, 2011.

TEIXEIRA, J.P.A.O controle de constitucionalidade no Brasil. Revista da Esmape, v. 13, n. 27, p. 249-264, jan./jun. 2008.

ZAGREBELSKY, G. El derecho dúctil. Ley, derechos, justicia. Madrid: Trotta, 2008. 